\title{
畄内マリファナ様物質としてのアラキドン酸含有 モノアシルグリセロール
}

\author{
杉浦 隆之 \\ 帝京大学楽学部衛生化学教室 \\ （干199-0195 神奈川県津久井郡相模湖町寸沢嵐 1091-1）
}

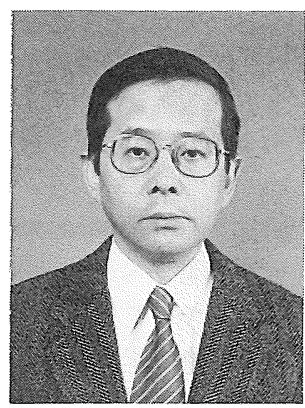

\section{Arachidonic Acid-Containing Monoacylglycerol as an Endogenous Cannabinoid Receptor Ligand}

\author{
Takayuki SugIURA \\ Faculty of Pharmaceutical Sciences, Teikyo University \\ (1091-1, Suarashi, Sagamiko, Tsukui-gun, Kanagawa-ken 199-0195)
}

\begin{abstract}
Arachidonoylglycerol is a unique molecular species of monoacylglycerol isolated from rat brain and canine gut as an endogenous cannabinoid receptor ligand. 2-Arachidonoylglycerol was recently shown to induce a rapid transient increase in NG108-15 cells through a cannabinoid CB1 receptor-dependent mechanism. 2-Arachidonoylglycerol was also shown to induce a rapid transient increase in HL-60 cells through a cannabinoid CB2 receptor-dependent mechanism. Based on a structure-activity relationship, 2-arachidonoylglycerol was concluded a natural ligand for the $\mathrm{CB} 1$ receptor or $\mathrm{CB} 2$ receptor and both of which are primarily 2arachidonoylglycerol receptors. 2-Arachidonoylglycerol is a degradation product of inositol phospholipids in stimulated tissue. The CB1 receptor is involved in attenuation of the neurotransmission; 2-arachidonoylglycerol, produced and released on neuronal excitation, may possibly be essential for the slowing of neurotransmission. 2-Arachidonoylglycerol may also have important roles in the cardiovascular and immune systems, but this remains to be confirmed. A complete understanding of the physiological roles of 2-arachidonoylglycerol, a novel lipid mediator, awaits future studies.
\end{abstract}

Key words : cannabinoids, 2-arachidonoylglycerol, monoacylglycerol, anandamide, $\Delta^{9}$-tetrahydrocannabinol, marijuana

\section{1 はじめに}

マリファナ（大麻）を摂取すると，時間感覚・空間感 覚の混乱, 多幸感, 離人感, 幻覚, 眠気など神経系を中 心に大きな影響がみられる。マリファナの摂取はこのほ かにも, 頻脈, 結膜の充血, 記憶の障害, 眼圧低下, 食 欲増進，気管支拡張など様々な反応を引き起こす。マリ ファナのもつこのような作用は， $\Delta^{9}$-テトラヒドロカン ナビノール（Fig. 1）を中心とする一連の化合物（カン ナビノイドと総称される）によるものであるということ が 1960 年代に，イスラエルの Mechoulam らによって明 らかにされた。カンナビノイドの作用機序は長い間不明
であったが，1990 年になって受容体遺伝子がクローニ ングされたことから，受容体 (カンナビノイド受容体) を介して作用しているということが明確となった ${ }^{1)}$ 。そ して，受容体が存在することから，内在性のリガンドが 存在することが示唆され, 検索の結果, 今日までにアナ ンダミド2) (N-アラキドノイルエタノールアミン) (Fig. 1）とアラキドン酸含有モノアシルグリセロールの一種 である2-アラキドノイルグリセロール3),4) (2-AG と略す こともある）（Fig. 1）という二つの中性脂質が候補物 質として単離, 報告されている。本稿では, カンナビノ イド受容体の内在性リガンド, 特に, 真の内在性リガン ドであると目される2-アラキドノイルグリセロールの 
<smiles>CCCCCc1cc(O)c2c(c1)O[C@]1(C)CCC(C)CC21</smiles>

(-) $\Delta^{9}$-Tetrahydrocannabinol

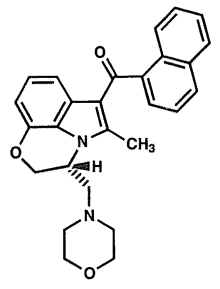

WIN55212-2

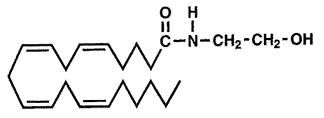

N-Arachidonoylethanolamine (Anandamide)

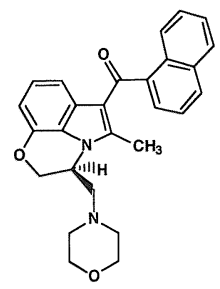

WIN55212-3<smiles>O=C(NCCO)OCCN1C=CC2(C=CC=CC2)C=C1</smiles>

2-Arachidonoylglycerol

Fig. 1 Chemical Structures of Several Cannabinoid Receptor Ligands.

作用・代謝・体内分布・意義を中心に概説したい。

\section{2 カンナビノイド受容体}

カンナビノイド受容体 (マリファナ受容体) としては,

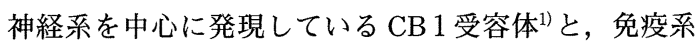
を中心に発現している CB 2 受容体 ${ }^{5}$ の二つが，これま でに同定，遺伝子クローニングされている（Table 1)。 $\mathrm{CB} 1$ 受容体, $\mathrm{CB} 2$ 受容体ともに 7 回膜貫通, $\mathrm{G}$ タンパ ク質共役型の受容体で，ヒトの場合，CB 1 受容体は 472 個の, CB 2 受容体は 360 個のアミノ酸から成って いる。CB 1 受容体は, 脳ではグルタミン酸や $\gamma$-アミノ 酪酸（GABA）の受容体に匹敵するほど多量に発現して いるという6)。特に多く発現しているところは線条体や 淡蒼球, 黒質, 海馬, 小脳, 大脳皮質などで, こういっ たところに発現していることから，CB 1 受容体は運動 の調節, 記憶, 学習などの脳の高度機能の調節に関与し ているものである可能性が高いと考えられる。一方,
CB 2 受容体は脾臓や扁桃腺，マクロファージ，B リン パ球などに多量に発現しており ${ }^{5)}$, 詳細は不明であるが, 炎症・免疫反応の調節に何らかの寄与をしていると考え られている。

\section{3 アナンダミド：最初の内在性カンナビノイド 受容体内在性リガンド}

最初の内在性カンナビノイド受容体リガンドであるア ナンダミド (N-アラキドノイルエタノールアミン) は, 1992 年にイスラエルの Mechoulam のグループによって ブタの脳から単離されたものである2)。この物質はアラ キドン酸とエタノールアミンが酸アミド結合したもの で, カンナビノイド受容体に対する強い結合活性を持っ ている。しかし，結合活性に比べてアゴニストとしての 活性は概して弱く, 一種の部分作動薬 (partial agonist) である可能性が高い。筆者らはラットの脳に存在するア ナンダミドの量を詳しく調ベ, アナンダミドが少なくと

Table 1 Cannabinoid Receptors.

\begin{tabular}{ll}
\hline \multicolumn{1}{c}{ CB1 } & \multicolumn{1}{c}{ CB2 } \\
\hline$\cdot$ (1990)Matsuda et al. & $\cdot(1993)$ Munro et al. \\
$\cdot$ Seven-transmembrane, & $\cdot$ Seven-transmembrane, \\
G protein-coupled receptor & G protein-coupled receptor \\
$\cdot 472$ Amino acids & $\cdot 360$ Amino acids \\
$\cdot$ Brain, NG108-15 cells etc. & $\cdot$ Spleen, HL-60 cells etc. \\
(The nervous system) & (The immune system) \\
\hline
\end{tabular}


も正常な脳にはほとんど存在していないこと，生合成 ルートとして選択的で効率のよいものが存在しないこと などを明らかにした7),8同様の結果は他のいくつかの グループによっても報告されて打り ${ }^{9)}$ 11), 総合的にみて, アナンダミドがカンナビノイド受容体の本来の生理的な リガンドであるという可能性は非常に低いと考えられ る。

\section{4 カンナビノイド受容体リガンドとしての 2-アラキドノィルグリセロールの発見}

筆者らはアナンダミド以外に真の内在性リガンドがあ るのではないかと推定して検索を行い，1995 年にラッ 卜の脳に比較的多量に存在しているアラキドン酸含有モ ノアシルグリセロールの一種，2-アラキドノイルグリセ ロールにカンナビノイド受容体に対する結合活性のある ことを明らかにした3)。期を同じくして Mechoulam らも イヌの腸から 2-アラキドノイルグリセロールを単離し, カンナビノイド受容体に対する結合活性のあることを報 告した4)。しかし，当時はアナンダミドに注目が集まっ ており，2-アラキドノイルグリセロールが注目されるこ とはほとんどなかった。Mechoulam 自身も，アナンダ ミドの発見者であったせいか，2-アラキドノイルグリセ ロールにはそれほど注意を払っていなかったようであ る。1998 年になるまで，2-アラキドノイルグリセロー ルに関する研究結果は彼らのグループからは出ていな い。一方，筆者らは 1995 年の発表後も2-アラキドノイ ルグリセロールに関する研究を続けた。筆者らが 2-ア ラキドノイルグリセロールに注目し続けた理由は，2-ア ラキドノイルグリセロールが，アナンダミドと違って比 較的ありふれた物質であるということ，構造から容易に 想像されるように，アラキドン酸含有リン脂質の代謝充 進の際に生成しうる物質であるというところにあった。

\section{2-アラキドノイルグリセロールの作用}

筆者らは 1996 年に，2-アラキドノイルグリセロール が CB 1 受容体を発現しているニューロブラストーマと グリオーマのハイブリッド NG 108-15 細胞の細胞内カ ルシウムイオン濃度を速やかに一過的に上昇させること を全く偶然に見い出した ${ }^{12)}$ 。光れまで，カンナビノイド 受容体アゴニストが，カンナビノイド受容体を介して細 胞内カルシウムイオン濃度を上昇させるという報告はな されていなかったので, 早速, 他のカンナビノイド受容 体リガンドにも同様の活性があるかどうか調べた。その 結果，カンナビノイド受容体アゴニストとしての作用を 有することが知られているアミノアルキルインドールの 一種 WIN 55212-2（Fig. 1) に，2-アラキドノイルグリ セロールと同様の活性のあることがわかった。一方， WIN 55212-2 の光学異性体で, カンナビノイド受容体
リガンドとしての活性を持たないとされているWIN 55212-3（Fig. 1）には活性は全くなかった。カルシウ ムイオン濃度の一過的上昇という細胞応答は, カンナビ ノイド受容体リガンドのアゴニストとしての活性をよく 反映するものと考觉られる。

遊離のアラキドン酸には活性は全くなく, シクロオキ シゲナーゼ阻害剤であるインドメタシンやリポキシゲ ナーゼ阻害剤であるノルジヒドログアイアレチン酸で細 胞を前処理しても影響が全くみられないことから，2-ア ラキドノイルグリセロールが何らかのアラキドン酸代謝 物になって効いているのではないと考えられた。次に脱 感作の実験を行った。その結果，細胞を2-アラキドノ イルグリセロールで前処理すると，WIN 55212-2 に対 する反応性が消失すること, 逆に, WIN 55212-2 で前 処理した細胞は，2-アラキドノイルグリセロールに対す る反応性を消失していることがわかった。この結果は， 2-アラキドノイルグリセロールと WIN 55212-2 が共通 の受容体（カンナビノイド受容体）に作用しているとい うことを明確に示すものである。なお，2-アラキドノイ ルグリセロールやWIN 55212-2 によって引き起こされ る細胞内カルシウムイオン濃度の上昇は, カンナビノイ ド CB 1 受容体特異的アンタゴニストである SR 141716 A（Fig. 1）で細胞を前処理することによって完全に消 失することから, カンナビノイド CB 1 受容体を介した ものであることが確認された。

細胞内カルシウムイオン濃度の上昇の機構にはまだ不 明な点も残っているが，百日咳毒素やホスホリパーゼ C の阻害郕 U 73122 で細胞を前処理することによって反応 が消失することなどから，Gi ないし Go 打よびホスホ リパーゼ C を介する細胞内カルシウムイオン動員系が 関与しているものと思われる ${ }^{12), 13)}$ 。細胞内カルシウムイ オン濃度が一過的に上昇することの生理的な意義は不明 であるが，この反応は鋭敏で，迅速に多数の検体を調べ ることができることなど幾つかの大きな特長を有してお り，アゴニストとしての活性を検索する上で極めて有用 なものである。

筆者らはこの系を利用して多数のカンナビノイド受容 体リガンドのアゴニストとしての活性を詳細に調べ た ${ }^{12) ~ 14) 。 2-ア ラ キ ト ゙ ノ イ ル ク ゙ リ セ ロ ー ル に よ っ て 引 き ~}$ 起こされる細胞内カルシウムイオン濃度の一過的上昇 は， $0.3 \mathrm{nM}$ という低い濃度から観察され， $\mathrm{EC}_{50}$ は約 30 nM であった（Fig. 2)。2-アラキドノイルグリセロール はWIN 55212-2 と同様, この系で完全作動薬（full agonist）として作用する。これに対し，最初の内在性 カンナビノイド受容体リガンドとして見い出されたアナ ンダミド（Fig. 2） やマリファナの活性成分である $\Delta^{9-}$ テトラヒドロカンナビノールのアゴニストとしての活性 は比較的弱く，いずれも部分作動薬 (partial agonist) 

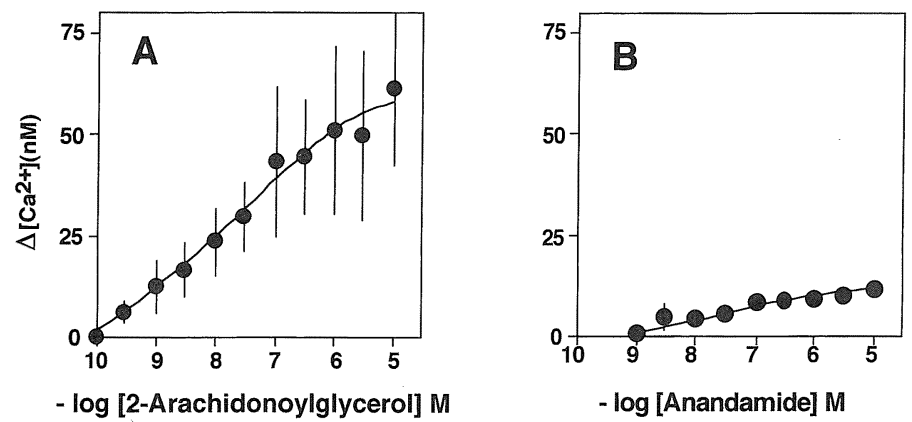

Fig. 2 2-Arachidonoylglycerol and $N$-Arachidonoylethanolamine (Anandamide) Induce Rapid Transient Increases in NG108-15 Cells. Cells were loaded with Fura-2/AM and then challenged with 2-arachidonoylglycerol (A) or anandamide (B). Changes in the intracellular free $\mathrm{Ca}^{2+}$ concentrations were determined in a $\mathrm{Ca}^{2+}$ analyzer, $\mathrm{CAF}-100^{14)}$.

として作用することがわかった。次に，各種モノアシル グリセロールの活性を調べた。パルミチン酸やオレイン 酸などを結合したモノアシルグリセロールには，活性は 全くみられない。リノール酸や $\alpha$-リノレン酸, $\gamma-$ リノ レン酸などを結合したモノアシルグリセロールの活性も ごく弱いものでしかない。また, 炭素数 22 の脂肪酸を もつモノアシルグリセロールの活性もごく弱いものに過 ぎなかった。こういったことから，脂肪酸部分は炭素数 20 の高度不飽和脂肪酸であることが重要と考えられた。 興味あることに，3種類のエイコサトリエン酸を結合し たモノアシルグリセロールの活性には大きな差のあるこ とがわかった。グリセロールの 2 位に $20: 3(\mathrm{n}-9)$ をもつ モノアシルグリセロールには2-アラキドノイルグリセ ロールに匹敵する強い活性があったが, $20: 3(\mathrm{n}-6)$ をも つものの活性は弱く，20:3(n-3) をもつものにはごく弱 い活性が認められるのみであった。この結果は, $\mathrm{n}-3, \mathrm{n}-6$, n-9 といった違いよりも, エステル結合に近い部分の構 造，特に $\Delta 5$ の位置に二重結合の存在することがカンナ ビノイド受容体アゴニストとして強い活性を発揮するた めに重要であるということを強く示唆するものである。 たしかに， $\Delta 5$ の位置に二重結合を有するエイコサペン タエン酸 $(20: 5(\mathrm{n}-3))$ をグリセロールの 2 位にもつモ ノアシルグリセロールも，2-アラキドノイルグリセロー ルよりは弱いながら，かなり強い活性を持っている。

次に，グリセロールとアラキドン酸の結合様式をエス テル結合以外のものに変えてみた。2-アラキドノイルグ リセロールのエステル結合をエーテル結合に変えたもの には，2-アラキドノイルグリセロールよりは弱いながら 活性が認められたが, 酸アミド結合やメチレン結合に変 えたものには，ごく弱い活性しか認められなかった。結 合様式は，エステル結合であることが重要であると考え られる。また，結合位置についてみると，1(3)-アラキ
ドノイルグリセロールの活性が, 2-アラキドノイルグリ セロールの活性の $1 / 10$ から $1 / 30$ 程度と弱いことから， グリセロール骨格の 2 位にアラキドン酸が付いているこ とが重要と考えられた。また，骨格をグリセロールでな く,エチレングリコールに変えたものや,プロパンジオー ルに変えたものにもアゴニストとしての活性はあるもの の，2-アラキドノイルグリセロールのそれに比べると弱 いものであることがわかった。

以上の結果は, カンナビノイド CB 1 受容体が, 2-ア ラキドノイルグリセロールの構造を厳密に認識している ということ，すなわち， CB 1 受容体の本来の生理的な リガンドが，2-アラキドノイルグリセロールであるとい

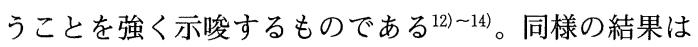
カンナビノイド CB 2 受容体を発現しているヒト白血病 細胞 HL-60 細胞を用いた奉験でも得られており ${ }^{15)}$ ，力 ンナビノイド受容体は CB 1 受容体, CB 2 受容体とも に本来は2-アラキドノイルグリセロールに対する受容 体である可能性が高い。

2-アラキドノイルグリセロールに関しては,このほか, CB 1 受容体あるいは CB 2 受容体を発現させた細胞の アデニレートシクラーゼを阻害して細胞内サイクリック AMP レベルを低下させること4), 電気刺激したマウス の精管の収縮を抑制すること午, in vitro における肧の発 生・分化を抑制すること ${ }^{16)}$, リンパ球の増殖を促進ある いは抑制すること ${ }^{17)}$, 動物に投与すると血圧低下などを 引き起こすことなどが報告されている(18),19)。ただし, 動 物に投与した際にみられる反応や, リンパ球に加えたと きにみられる変化が，2-アラキドノイルグリセロールそ のものの作用によるかどうかは不明である。Jarai ら ${ }^{20)}$ は，2-アラキドノイルグリセロールによって引き起こさ れる血圧低下の一部はアラキドン酸代謝物によるもの で，一部はカンナビノイド CB 1 受容体を介したもので 
あることを示した。これまでに2-アラキドノイルグリ セロールの作用として報告されたものの中には，2-アラ キドノイルグリセロールに由来するアラキドン酸ないし その代謝物によって引き起こされたものと考光られる場 合があるので，注意を要する。いずれにしても，2-アラ キドノイルグリセロールの生理作用についてはまだ研究 がそれほど進んで打らず，充分な量の情報が蓄積してい るとは言い難い状態である。2-アラキドノイルグリセ ロールの生理作用の全容の解明のためには, 今後, より 広い視野・視点からの検討が必要である。

\section{2-アラキドノイルグリセロールの代謝}

動物細胞では，アラキドン酸は，通常，リン脂質のグ リセロール骨格の 2 位に結合しているということから想 像できるように，2-アラキドノイルグリセロールは，主 として, アラキドン酸含有のリン脂質が分解を受けたと きに生成する。生成ルートとしては，ホスホリパーゼ C などの作用によってイノシトールリン脂質などから生じ たアラキドン酸含有のジアシルグリセロールが, ジアシ リグリセロールリパーゼの作用によって分解を受けて 2-アラキドノイルグリセロールを生成するというルート や，ホスホリパーゼ $\mathrm{A}_{1}$ の作用によってアラキドン酸含 有のイノシトールリン脂質などから生じた2-アシル型 のリゾリン脂質が, さらにホスホリパーゼ Cによって 分解を受けて2-アラキドノイルグリセロールを生成す るというルートなどが考えられる゙）(Fig. 3)。このほか， 一部の 2-アラキドノイルグリセロールは, 脳に比較的 多量に存在するアラキドン酸含有リゾホスファチジン酸 が脱リン酸化されて生成したものであるという可能性も ある3)。いずれにしても2-アラキドノイルグリセロール の生成は, 情報伝達に伴って起きるイノシトールリン脂 質などの代謝元進と密接に関連したものである可能性が 高い。

筆者らは, 脳ホモジネートをカルシウムイオンの存在 下インキュベートすると，2-アラキドノイルグリセロー
ルが速やかに選択的に生成することを観察している21)。 2-アラキドノイルグリセロールの生成と平行して, アラ キドン酸含有ジアシルグリセロールの生成も認められる こと，アラキドン酸含有のジアシルグリセロールを添加 すると，2-アラキドノイルグリセロールの生成が増大す ること,アイソトープ標識したアラキドン酸を結合させ たホスファチジルイノシトールを添加した場合には，ジ アシルグリセロールの生成と平行して2-アラキドノイ ルグリセロールの生成が認められるが, ホスファチジル エタノールアミンやホスファチジルコリンを添加した場 合には2-アラキドノイルグリセロールの生成がみられ ないことなどから,少なくともホモジネートの場合には, 2-アラキドノイルグリセロールは，イノシトールリン脂 質から, 主として, ジアシルグリセロールを経由する経 路で生成してくるものと考えられる。

一方，2-アラキドノイルグリセロールの分解・代謝 ルートとしては，モノアシルグリセロールリパーゼやア ナンダミドアミドヒドロラーゼによって遊離アラキドン 酸とグリセロールに分解されるルートや，モノアシルグ リセロールキナーゼによってリン酸化され, 別の生理活 性脂質であるリゾホスファチジン酸に変換されるルート などがある゙) $($ Fig. 3)。

\section{2-アラキドノイルグリセロールの体内分布}

2-アラキドノイルグリセロールは動物の体内に比較的 広く存在する。断頭したラットの脳には $3.4 \mathrm{nmol} / \mathrm{g}$ の 2-アラキドノイルグリセロールと, $1.4 \mathrm{nmol} / \mathrm{g}$ の 1 (3) アラキドノイルグリセロールが存在していた ${ }^{21)}$ 。脳以外 にも, 肝臓や腎臓, 脾臓, 肺などで存在が認められたが, 血漿中にはほとんど存在していない211。Bisogno ら ${ }^{22)}$ は, 脳の中でも, 海馬や脳幹, 線条体などで2-アラキド, イルグリセロールのレベルが高いと報告している。この ほか, ラットや牛の網膜で 2 -アラキドノイルグリセロー ルが検出されたとの報告もある23),24)。最近，筆者らは， 断頭後, 脳内の 2-アラキドノイルグリセロールの量が

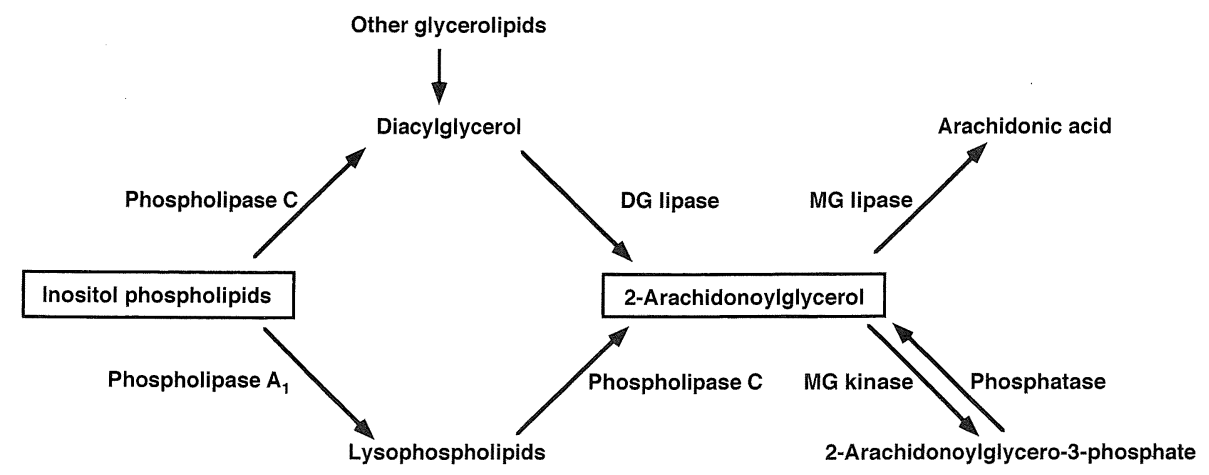

Fig. 3 Metabolic Pathways of 2-Arachidonoylglycerol. 
速やかに著しく上昇することを見い出した（未発表デー タ)。液体窒素につけることにより瞬時に殺したラット の脳内の 2-アラキドノイルグリセロールのレベルは $0.23 \mathrm{nmol} / \mathrm{g}$ で，これは断頭して殺したラットの脳に存 在していた2-アラキドノイルグリセロールのレベルの 約十五分の一にすぎない。これまでの全脳，あるいは脳 の各部位に存在している2-アラキドノイルグリセロー ルについての分析では，断頭のショックで，あるいは脳 を取り出す過程などで artifactに生成したものをみてい た可能性がある。2-アラキドノイルグリセロールを定量 する場合には細心の注意が必要である。

\section{2-アラキドノイルグリセロールの意義}

カンナビノイド受容体の本来の内在性リガンドは 2アラキドノイルグリセロールであると考えられる。 $\Delta^{9-}$ テトラヒドロカンナビノールの作用の少なくとも一部 は，2-アラキドノイルグリセロールの作用を擋乱するこ とによって引き起こされたものであろう。カンナビノイ ド受容体や 2-アラキドノイルグリセロールの本来の機 能が，幻覚などを起こすことにあるのではないと思われ る ${ }^{25)} 277$ 。

ところで，前述したように，2-アラキドノイルグリセ ロールは，主として，アラキドン酸含有のリン脂質が分 解を受けたときに生成すると考えられることから，カン ナビノイド受容体の機能と，イノシトールリン脂質等の 代謝立進は密接にリンクしたものであるという可能性が
浮上してきた。確かに，カンナビノイド受容体が多く存 在する線条体, 海馬, 小脳などは, イノシトールリン脂 質等の代謝充進が活発に起きているところでもある6)。 カンナビノイド受容体は，一般に，神経伝達を抑制的に 制御するという機能を担っているので，イノシトールリ ン脂質等の代謝立進を伴う情報伝達の際に生成する 2アラキドノイルグリセロールには，カンナビノイド受容 体を介して神経伝達にネガティブフィードバックをかけ るという役割があるものと思われる25 27) $($ Fig. 4)。筆 者らは中枢神経興奮薬であるピクロトキシニンをラット

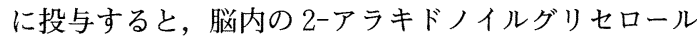
の量が速やかに 4 6 倍に増加するということを見い出 している ${ }^{28)}$ 。一方，筆者らは，分化させて電位依存性力 ルシウムチャンネル等を発現させた NG 108-15 細胞で は，2-アラキドノイルグリセロールが脱分極に伴う細胞 内カルシウムイオン濃度の上昇を抑制することも見いだ している29)。シナプス前終末に打けるカルシウムイオン 濃度の上昇は，神経伝達物質の放出等に必須であること から，2-アラキドノイルグリセロールは，カルシウムイ オン濃度を調節することにより神経伝達物質の放出を調 節しているという可能性が考えられる。最近, Stella $5^{30}$ は，2-アラキドノイルグリセロールがラット海馬 CA 1 領域の長期増強（LTP）を抑制することを報告した。 この抑制のメカニズムの詳細はまだ不明であるが，可能 性の一つとして前終末からの神経伝達物質の放出が抑制 されたためということが考兮れる。2-アラキドノイル

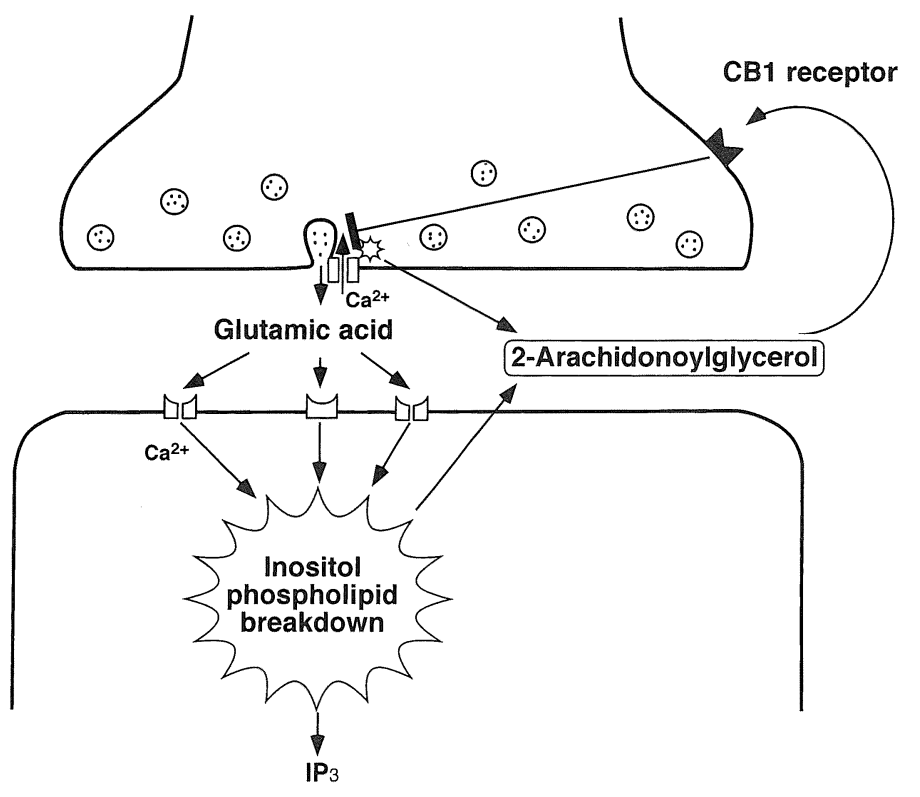

Fig. 4 A Possible Role of 2-Arachidonoylglycerol in the Regulation of Neurotransmission. 
グリセロールは前終末だけでなく，後終末等に作用して いる可能性もあるが，いずれにしても，神経伝達調節因 子としての 2-アラキドノイルグリセロールの可能性は, 今後の興味ある研究課題であるとい光よう。なお，2-ア ラキドノイルグリセロールは，血管内皮細胞が産生する こと，血管平滑筋細胞等にカンナビノイド $\mathrm{CB} 1$ 受容体 が発現していることなどからみて，神経系だけでなく， 血管系においても何らかの重要な役割を演じているもの である可能性がある31)。こういった可能性の追求も，今 後に残された課題である。また, 炎症・免疫反応のモジュ レーターとしての 2-アラキドノイルグリセロールの役 割の追求も，今後の重要な研究課題の一つである。

$$
9 \text { おわりに }
$$

2-アラキドノイルグリセロールは, 脂質メディエー ターとしての役割を担っていることが明らかになった初 めてのモノアシルグリセロールである。その作用は神経 系から, 血管系, 炎症・免疫系, 生殖系まで多岐にわた るものである可能性がある。ただ，前述したように，2アラキドノイルグリセロールが注目を集めるようになっ てからはまだ日が浅く，十分なことはわかっていないと いうのが実情である。プロスタグランジンや PAF，リ ゾホスファチジン酸などに続く，この新しい脂質メディ エーターの生理的意義や体内での動態などその全容の解 明は，今後の研究にまつところが大きい。

（受付：2000 年 5 月 8 日，受理：2000 年 6 月 1 日）

\section{文献}

1) L.A. Matsuda, S.J. Lolait, M.J. Brownstein, A.C. Young, T.I. Bonner, Nature, 346, 561 (1990).

2) S. Munro, S, K.L. Thomas, M. Abu-Shaar, Nature, 365, 61 (1993).

3) W.A. Devane, L. Hanus, A. Breuer, R.G. Pertwee, L.A. Stevenson, G. Griffin, D. Gibson, A. Mandelbaum, A. Etinger, R. Mechoulam, Science, 258, 1946 (1992).

4) T. Sugiura, S. Kondo, A. Sukagawa, S. Nakane, A. Shinoda, K. Itoh, A. Yamashita, K. Waku, Biochem. Biophys. Res. Commun., 215, 89 (1995).

5) R. Mechoulam, S. Ben-Shabat, L. Hanus, M. Ligumsky, N.E. Kaminski, A.R. Schatz, A. Gopher, S. Almog, B.R. Martin, D.R. Compton, R.G. Pertwee, G. Griffin, M. Bayewitch, J. Barg, Z. Vogel, Biochem. Pharmacol., 50, 83 (1995).

6) M. Herkenham, in "Cannabinoid Receptors" R.G. Pertwee, Ed., Academic Press, London, p.145 (1995).

7) T. Sugiura, S. Kondo, A. Sukagawa, T. Tonegawa, S. Nakane, A. Yamashita, Y. Ishima, K. Waku, Eur. J. Biochem., 240, 53 (1996).
8) T. Sugiura, S. Kondo, A. Sukagawa, T. Tonegawa, S. Nakane, A. Yamashita, K. Waku, Biochem. Biophys. Res. Commun., 218, 113 (1996).

9) P.C. Schmid, R.J. Krebsbach, S.R. Perry, T.M. Dettmer, J.L. Maasson, H.H.O Schmid., FEBS Lett., 375, 117 (1995). Corrigendum, FEBS Lett., 385, 124 (1996).

10) K. Kempe, F.-F. Hsu, A. Bohrer, J. Turk, J. Biol. Chem., 271, 17287 (1996).

11) H. Cadas, E. di Tomaso, D. Piomelli, J. Neurosci., 17, 1226 (1997).

12) T. Sugiura, T. Kodaka, S. Kondo, T. Tonegawa, S. Nakane, S. Kishimoto, A. Yamashita, K. Waku, K,. Biochem. Biophys. Res. Commun., 229, 58 (1996).

13) T. Sugiura, T. Kodaka, S. Kondo, S. Nakane, H. Kond, K. Waku, Y. Ishima, K. Watanabe, I. Yamamoto, J. Biochem., 122, 890 (1997).

14) T. Sugiura, T. Kodaka, S. Nakane, T. Miyashita, $S$. Kondo, Y. Suhara, H. Takayama, K. Waku, C. Seki, N. Baba, Y. Ishima, J. Biol. Chem., 274, 2794 (1999).

15) T. Sugiura, S. Kondo, S. Kishimoto, T. Miyashita, S. Nakane, T. Kodaka, Y. Suhara, H. Takayama, K. Waku, J. Biol. Chem., 275, 605 (2000).

16) B.C. Paria, W. Ma, D.M. Andrenyak, P.C. Schmid, H.H.O. Schmid, D.E. Moody, H. Deng, A. Makriyannis, S.K. Dey, Biol. Reprod., 58, 1490 (1998).

17) M. Lee, K.H. Yang, N.E. Kaminski, J. Pharmacol. Exp. Ther., 275, 529 (1995).

18) K. Varga, J.A. Wagner, D.T. Bridgen, G. Kunos, FASEB J., 12, 1035 (1998).

19) R. Mechoulam, E. Fride, S. Ben-Shabat, U. Meiri, M. Horowitz, Eur. J. Pharmacol., 362, R1 (1998).

20) Z. Jarai, J.A. Wagner, S.K. Goparaju, L. Wang, R.K. Razdan, T. Sugiura, A.M. Zimmer, T.I. Bonner, A. Zimmer, G. Kunos, Hypertension, 35, 679 (2000).

21) S. Kondo, H. Kondo, S. Nakane, T. Kodaka, A. Tokumura, K. Waku, T. Sugiura, FEBS Lett., 429, 152 (1998).

22) T. Bisogno, F. Berrendero, G. Ambrosino, M. Cebeira, J.A. Ramos, J.J. Fernandez-Ruiz, V. Di Marzo, Biochem. Biophys. Res. Commun., 256, 377 (1999).

23) A. Straiker, N. Stella, D. Piomelli, K. Mackie, H.J. Karten, G. Maguire, Proc. Natl. Acad. Sci. USA, 96, 14565 (1999).

24) T. Bisogno, I. Delton-Vandenbroucke, A. Milone, M. Lagarde, V. Di Marzo, Arch. Biochem. Biophys., 370, 300 (1999).

25）杉浦隆之, 小高友子, 近藤佐知子, 中根慎治, 和 久敬蔵, 細胞工学, 17, 746 (1998).

26）杉浦隆之，近藤佐知子，中根慎治，和久敬蔵，蛋 
白質核酸酵素，44，1104 (1999).

27) T. Sugiura, K. Waku, Chem. Phys. Lipids, in press.

28) T. Sugiura, N. Yoshinaga, S. Kondo, K. Waku, Y. Ishima, Biohem. Biophys. Res. Commun., 271, 654 (2000).

29) T. Sugiura, T. Kodaka, S. Kondo, T. Tonegawa, S. Nakane, S. Kishimoto, A. Yamashita, K. Waku,
Biochem. Biophys. Res. Commun., 233, 207 (1997).

30) N. Stella, P. Schweitzer, D. Piomelli, Nature, 388, 773 (1997).

31) T. Sugiura, T. Kodaka, S. Nakane, S. Kishimoto, S. Kondo, K. Waku, Biochem. Biophys. Res. Commun., 243, 838 (1998). 


\title{
日本油化学会誌本号掲載 論文要旨
}

\section{[総説］脳内マリファナ様物質としてのアラキドン酸含有 モノアシルグリセロール}

\author{
杉 浦 隆 之 \\ 帝京大学薬学部衛生化学教室 \\ （勈199-0195 神奈川県津久井郡相模湖町寸沢嵐 1091-1）
}

2-アラキドノイルグリセロールは, ラットの脳やイヌの腸から取り出された一種のモノアシルグリセロールで, カンナビノイド受容体の内在性のリガンドであることが明らかにされた物質である。最近，我々は2-アラキドノ イルグリセロールが培養神経系細胞である NG 108-15 細胞の細胞内カルシウムイオン濃度を, カンナビノイド $\mathrm{CB} 1$ 受容体依存的に, 速やかに一過的に上昇させることを見い出した。我々は, さらに, 培養白血病細胞であ る HL-60 細胞の細胞内カルシウムイオン濃度を, カンナビノイド CB 2 受容体依存的に, 速やかに一過的に上昇 させることも見い出している。構造活性相関を調べた実験の結果から, 我々は, CB 1 受容体の場合も， CB 2 受 容体の場合も，本来の生理的なりガンドは 2-アラキドノイルグリセロールで，カンナビノイド受容体は，本来は 2-アラキドノイルグリセロール受容体であるという結論に至った。2-アラキドノイルグリセロールはイノシトー ルリン脂質代謝立進の際に生成する物質であるということ, カンナビノイド CB1 受容体の機能が, 神経伝達を 抑制的に制御するものであることを考えると，神経興奮に伴って生成した2-アラキドノイルグリセロールには， 一旦起こった神経の興奮にブレーキをかけるという重要な役割のある可能性が考えられる。2-アラキドノイルグ リセロールについては，このほか，血管系や炎症・免疫系において何らかの重要な役割を演じている物質である という可能性も考えられる。2-アラキドノイルグリセロールの生理的役割の詳細は，今後の研究によって明らか にされて行くであろう。

（連絡者：杉浦隆之） Vol.49, No.8，777（2000）

\section{[報文］２つのエステル基を有するビス第 4 級アンモニウム 塩型分解性界面活性剂の合成と物性}

\author{
小野大助・山村伸吾 - 中村正樹 - 武田徳司 \\ 大阪市立工業研究所 \\ （干536-8553 大阪府大阪市城東区森之宮 1-6-50）
}

本稿では，出発物質として天然物由来品である1-O-アルキルグリセロールを使用し，これをエステル化，第 四級アンモニウム化して酸またはアルカリにより分解する機能を備えたカチオン型分解性界面活性剂を開発し た。これらは，二親水基型ということでいずれも優れた水溶性を示した。 $\mathrm{cmc}$ は，通常の活性剤と比べた場合， アルキル鎖が同じものどうしでは, 約 1 オーダー小さくなり，ミセル形成能が優れていた。化学分解性は，アル カリ条件下では, $0.01 \mathrm{M}$ で添加直後, $0.005 \mathrm{M}$ では約 1 日で分解した。酸分解性は, アルカリに比べ遅く $1 \mathrm{M}$ では約 1 週間かまたはそれ以上， $2 \mathrm{M}$ では約 5 日を要した。活性污泥による生分解性を測定した結果，ドデシル トリメチルアンモニウムブロマイドの生分解性が約 10\%であったのに対し, 本研究の分解性活性剂は約 $40 \%$ と カチオン型の活性剤としては良好な值であった。さらに, 分解性活性剤の特徵を活かし活性剤をあらかじめ加水 分解したものを測定したところ約 $80 \%$ と大幅に向上し，非常に優れた生分解を示した。

（連絡者：武田徳司） Vol.49，No.8，785（2000） 